DEPARTMENT OF COMPUTER SCIENCE

UNIVERSITY OF ILLINOIS

URBANA, ILLINOIS

RELEAEED FOR ANNOUNCEMENT

IN NUCLEAR SCIENCE ABSTRACTS

\title{
Specifications for Multifunction Storage Unit Type I
}

by

W. J : Kubitz and D. C. Rollenhagen

File $110.550-66$

February 22, 1966

LEAL NOTICE LEGA L D
account of Government sponsored work. Nef the commission:
acting on behalf of the accuThis report was preplesion, nor any pertation, expressed or ined in this report, or hot infring States, nor the comy warranty or repres of the Information conclosed in this report mase A. Makes any was or usefulness of mad, or process drscle for damages result racy, complomation, apparatus, methe inse of, or for in this report.

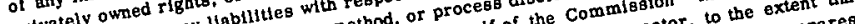

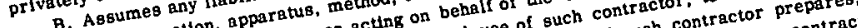
B. As information, appa "person acting on bomployee of such cof such contractor prepartract use of any inlo in the above, commlsston, or emplon, or employee of the employment As used lin the of the cor the commiseton, or pursuant

ployee or coyee or contractor al to, any informach contractor.

auch entates, or provlde ace employment

disseminatomisston, or his

with the Com 


\section{DISCLAIMER}

This report was prepared as an account of work sponsored by an agency of the United States Government. Neither the United States Government nor any agency Thereof, nor any of their employees, makes any warranty, express or implied, or assumes any legal liability or responsibility for the accuracy, completeness, or usefulness of any information, apparatus, product, or process disclosed, or represents that its use would not infringe privately owned rights. Reference herein to any specific commercial product, process, or service by trade name, trademark, manufacturer, or otherwise does not necessarily constitute or imply its endorsement, recommendation, or favoring by the United States Government or any agency thereof. The views and opinions of authors expressed herein do not necessarily state or reflect those of the United States Government or any agency thereof. 


\section{DISCLAIMER}

Portions of this document may be illegible in electronic image products. Images are produced from the best available original document. 


\section{0 "General Description}

The Multifunction Storage Unit, Type $I$ is a storage device capable of storing geometrical information in visual display form. The storage is accomplished by means of an electrostatic storage cathode ray tube. The Storage Unit consists of this storage tube and its associated circuitry. Associated circuitry. is considered to be all circuitry required by the storage tube itself which is necessary to make the unit a self-contained storage unit. 'The following six external signals are all that is required in order to write, store and erase in the unit: vertical deflection signal, horizontal deflection signal, gate signal, z axis signal, erase signal (local or remote) and $\mathrm{AC}$ power.

The erase signal causes the entire screen to be erased and primed for writing.

2.0 Specifications, Electrical

2.1 Vertical and Horizontal Deflection Amplifiers

Both vertical and horizontal deflection amplifiers are a part of the unit and satisfy the following specifications:

\section{1 .1 Sensitivity}

0.25 volts/Div MAX (nominal), a division is one-tenth of the side of a square inscribed inside the useful screen diameter of 4 inches or about 0.25 inches.

\subsubsection{Bandwidth}

Greater than $1.25 \mathrm{Mc}$ (3db point).

\section{1 .3 Rise Time}

Less than $0.3 \mu \mathrm{sec}$.

\section{1 .4 Input Attenuator}

XI, X5, X20 vclts/Div; AC or DC coupled, with 6: I gain between fixed positions. 
2.1.5. Input Impedance

1 meg or greater shunted by 50 pf or less.

\section{$2.2 \quad 2$ Axis Circuit}

2.2.1 . Input Impedance

$1 \mathrm{meg}$.

2.2 .2 Rise.Time

Less than $0.5 \mu \mathrm{sec}$.

2.3 Gate Circuit

2.3 .1 Polarity

Positive.

2.3 .2 . Input Impedance

100 $\mathrm{K}$ or greater.

2.3 .3 Rise Time

Lèss than $0.5 \mu \mathrm{sec}$.

$2.4 \quad$ Power Requirements

117 vac, $60 \mathrm{cps}$.

3.0 Specifications, Mechanical

3.1 Front Panel Controls

The following controls are located on the front panel (the display surface of the storage tube is flush with the front panel): focus, astigmatism, intensity, scale illumination, vertical and horizontal attenuator, vertical and horizontal position, storage threshøld adjustment, storage on-off, local erase, $Z$ axis input or gate selector and power on-off switch.

3.2 Front Panel Connectors

The following connectors are located on the front panel: ground, 
vertical and horizontal amplifier inputs, gate input, $\mathrm{Z}$ axis input; external erase.

\subsubsection{External Erase}

It should be possible to accomplish external erasure by means of contact closure.

\subsubsection{Vertical and Horizontal Deflection Amplifier Inputs}

Vertical and horizontal input connectors may be either UHF or BNC connectors .

\subsubsection{Gate and Z Axis Inputs}

Gate and $Z$ axis input connectors may be UHF, BNC or binding. posts.

\subsection{Bimensions}

Outside dimensions should be approximately 13 inches high $\mathrm{X}$ 10 inches wide $X 22$ inches deep.

4.0 Specifications, Storage Tube

4.1 Light Output

20 foot-lamberts.

4.2 Written Resolution

50 lines/inch minimum。

4.3 Contrast

The tube must be bistable with light and dark tones. 3:1 contrast ratio.

4.4 Storage Time

Infinite.

4.5 Writing Speed

$10^{6}$ inches/sec. 
4.6 Erasure Time

Less than $150 \mathrm{msec}$. from start of erase pulse until unit is again ready for writing.

4.7. Useful Screen Diameter

4 inches minimum.

4.8 Radius of Curvature

Flat.

$-4-$ 